\title{
NIST and ATP: Creating a New Relationship between Government and Industry
}

\author{
Sue MacBride ${ }^{t}$
}

Sue MacBride is a master of public administration candidate concentrating in management of state and local governments. Ms. MacBride received a bachelor of arts degree in political science cum laude from Wellesley College in 1991. She has worked with government contractors and non-profit groups including the Women's Legislative Network of Massachusetts, the Boston Water \& Sewer Commission, the Department of Housing and Urban Development, and the Department of Veterans Affairs. Ms. MacBride recently finished editing a manuscript for a book on benchmarking for best practices in the public sector.

\section{From NBS to NIST}

During the great Baltimore fire of 1904, fire companies from New York, Philadelphia, and Wilmington were unable to assist the struggling Baltimore clepartment because the out-of-town firefighters were unable to connect their equipment to Baltimore hydrants. ${ }^{1}$ Knowing that their efforts would be futile without functioning equipment, the visiting firemen could do nothing except watch as the blaze raged out of control. Recognizing that problems of this sort were a result of the great scientific and engineering progress of the previous century, Congress subsequently created the National Bureau of Standards on March 3, 1901. ${ }^{2}$ At that time, the agency's original mandate was to perform the research and development needed to create physical measurements and uniform commercial standards like those that would have saved downtown Baltimore.

For most of its 92-year history, the National Institute of Standards and Technology (NIST) has been known as the keeper of standards-measuring everything from the weight of a pingpong ball to the true length of a foot-as well as the distributor of thousands of calibrated samples to the benefit of many U.S. companies. In so doing, NIST became the site of world-class basic research, earned an excellent worldwide reputation, and was considered essential to U.S. participation in manufacturing and commerce.

In 1988, Congress recast NIST to address a political and economic crisis: U.S. industry was losing market share to foreign competitors. Economic indicators in that year revealed that America's balance of trace in manufactured goods had plunged from an $\$ 18.1$ billion surplus in 1981 to a $\$ 151$ billion deficit in $1986 .{ }^{3}$ Even high-tech electronic products had been running a growing negative trade balance since 1984, increasing 49 percent between 1985 and 1986. With the passing of the Omnibus Trade and
Competitiveness Act in August, 1988, NIST's mission and responsibilities were redefined and expanded. The agency was assigned a more daunting task: to help jump-start the economy and win back U.S. business markets by working with industry to develop innovative technologies. ${ }^{6}$

Today, NIST is a non-regulatory agency that works to promote economic growth by developing and applying technology, measurements, and standards in conjunction with American industry. Business concerns dominate NIST's agenda, and the agency, now a part of the Department of Commerce's Technology Administration, has become a top technology-funding minipower." More important than the heightening of NIST"s profile, the agency has also become the focus of an experiment in government-industry collaboration through the flagship Advanced Technology Program (ATP), which holds many implications for the role of the federal government in technological development and the future welfare of U.S. industry. This article examines the basic mission and structure of ATP and considers ATP's usefulness as a model for future government-industry relations.

\section{The Omnibus Trade and Competitiveness Act}

The drastic change in the bureau's fortunes began in 1988 with the passage of the Omnibus Trade and

Competitiveness Act. The basis for the act was the growing realization across the nation that fundamental changes in the structure of the world economy had undermined the advantages the United States once enjoyed. ${ }^{8}$ In the prelude to the Act, Congress found that 1) technology and manufacturing improvements depend upon research to develop measures and standards necessary for quality and reliability, as well as new technological processes to allow industry to incorporate new methods and discoveries into com- 
mercial products; 2) scientific progress, public safety, and product compatibility depend on common and precise methods and measures; and 3) the federal government should maintain a science, engineering, and technology laboratory to assist U.S. companies in implementing new processes and creating new products."

As a result of these findings the Act gave the Bureau a new name-the National Institute of Standards and Technology-and a new three-fold mandate with a clear emphasis on improving technology: to assist private sector initiatives to capitalize on advanced technology; to advance promising research and development (R\&D) projects to be employed in future commercial applications through cooperative efforts with industries and universities; and to promote shared risks, accelerated development, and the combination of skills necessary to strengthen America's manufacturing industries. ${ }^{10}$ According to the drafters of the Act, "The future well-being of the U.S. economy depends on a strong manufacturing base that requires continual improvements in manufacturing technology, quality control, and techniques for ensuring product reliability and cost-effectiveness." ${ }^{11}$

\section{The Advanced Technology Program}

Since the establishment of the agency, NIST has taken the lead in stimulating cooperation among U.S. industries to make technological breakthroughs. With the passage of the Omnibus Trade and Competitiveness Act, the Institute was thrown into the intense and fast-paced world of international technological competition. By redirecting NIST's efforts, Congress was leveraging federal power in the hope of stepping up the pace of the transfer of high-tech breakthroughs to the market, thereby reinvigorating the struggling U.S. manufacturing sector. According to Wil Lepkowski of Chemical \& Engineering Neus, NIST was "setting off to help make U.S. industry dominant once again in manufacturing technology.",

\section{Since the establishment of the agency, NIST bas taken the lead in stimulating cooperation among U.S. industries to make technological breaktbroughs.}

In accordance with the new mandate, NIST undertook several initiatives. First came the creation of the Industrial Extension Services Program through which the agency would transfer new information on manufacturing technol- ogy to businesses through collaborative workshops and seminars. Second was the Clearinghouse for State Technology Programs, which collected and analyzed the work of state governments in promoting technology for economic development. The Clearinghouse was followed in 1989 by the establishment of the Manufacturing Extension Program, which provided technology assistance to U.S. manufacturers through non-profit Manufacturing Extension Centers located within universities throughout the country. The fourth and final NIST initiative was the Advanced Technology Program (ATP). Of all these initiatives, the ATP is the linchpin of NIST's revamped mission.

ATP was created by the Technology Competitiveness Act of 1988 in response to the deteriorating condition of the U.S. competitive position in the world economy. ${ }^{13}$ Authors of the Act based their law on two premises: 1) that expensive and risky technology research and development (R\&D) tended to actually inhibit technology development and subsequent timely commercialization in private-sector firms, and 2) that foreign competitors such as Japan and Germany had mastered the principles of risk reduction by forming cost-shared public-private partnerships. ${ }^{\text {ld }}$ In short, Congress recognized that in order to bring about long-term economic growth for the United States, industry needed to move technology from the research phase to the marketplace at a much faster pace.

Implemented in 1990, ATP's structure was based on the fact that the root of America's technology problem was not the ability to conduct basic scientific research but rather the inability to bridge the gap between lab and marketplace, and that one source of America's competitiveness problem was the mismatch between the structural organization and function of key federal government programs and the changing nature of the global marketplace. ${ }^{15}$ To compensate for the weak links in the technology development chain, ATP makes competitive awards to industry on a cost-sharing basis for R\&D projects considered to have strong potential for increasing the competitiveness of U.S. industry and stimulating economic growth. ATP was modeled after a Japanese grant program of support for key industrial technologies, and was designed to provide seed money for research consortia and small businesses to speed commercial application of new technology in areas such as highdefinition television, advanced manufacturing, and superconductivity. ${ }^{16}$

One of the first beneficiaries of the program was X-Ray Optical Systems. Based in Albany, New York, X-ray qualified for a grant from NIST for $\$ 1.9$ million to develop $\mathrm{x}$-ray and neutron lenses from glass capillaries, an emerging 
technology with widespread commercial application potential. Other awards made by ATP include $\$ 1.2$ million to Non-volatile Electronics Inc. of Minnesota for research into new ways of manufacturing computer memory media, as well as similar projects in neural networks, thermal insulators, and plastic recycling methods. ${ }^{17}$

In the 1993 edition of the "Guide to NIST," Director Arati Prabhakar described the organization's strategy to turn itself from a simple measurement laboratory program with three small extra-mural programs into a "full-service technology development, funding, extension and quality improvement partner for U.S. industry. ${ }^{18}$ This new goal is clearly manifest in the ATP. The program's mission is to stimulate economic growth in the United States through technological development, and has transformed NIST into a new model of a federal agency that aggressively uses government funds to directly promote economic growth. The level and nature of collaboration inherent in ATP's design may serve as a blueprint for a new role for the federal government. Whether or not this role is appropriate is a matter of current and, no doubt, future debate.

\section{How the Program Works}

ATP is authorized to fund research programs involving individual companies or joint ventures between two or more firms. To guide the selection of grantee programs, ATP has several criteria which fall into the following categories: ${ }^{19}$

- scientific and technical merit;

- broad-based commercial benefits;

- technology transfer benefits;

- experience and qualifications of research teams;

- applicant's level of commitment toward completion of R\&D and subsequent commercialization; and

- quality of applicant's management team and organizational structure.

These criteria are designed to identify recipients who have well-defined R\&D plans and a clear vision of how technological success could be transformed into competitive, marketable ideas. Individual companies can receive up to $\$ 2$ million over three years, while awards to joint ventures can continue for five years. Dennis Cioffi of Physics Today notes that, "In contrast to most scientific grant proposals, ATP candidates have two requirements: technical and economic. The evaluation criteria include scientific and technical strength, as well as plans for eventual commercialization of the research and potential broad-based economic benefits. ${ }^{20}$ In order to fulfill programmatic goals, therefore, ATP combines two simple yet effective strategies.

First, like Japan's Ministry for International Trade \& Industry, ATP facilitates the commercialization of research by awarding matching grants to U.S. companies or joint ventures, thereby promoting government and private sector collaboration in the development of new technologies. ${ }^{21}$ This element of shared risk sets ATP apart from other scientific grant programs. The provision requiring grant winners to furnish half of the funds to implement the R\&D programs provides some insurance and reduces the risk of the government's investment of taxpayer dollars. ATP's condition that participating companies pay half the bill also ensures that these firms have a vested interest in the success of the projects and in timely commercialization of the results.

ATP's funding scheme has been characterized as lying somewhere between grants and contracts, yet having the best of both worlds. Unlike a contract, the program does not demand a specific product. Compared to a grant, the ATP provides more technical support and monitors a project's progress more closely. Through the combination of technical assistance and quarterly evaluation, ATP has government and industry working for and with each other.

\section{ATP's funding scheme has been characterized as lying somewhere between grants and contracts, yet baving the best of both worlds.}

Requiring all R\&D projects to be conducted in the grantee's facilities is the second strategy used to fulfill ATP's mission. In shaping the ATP, NIST administrators understood that reinventing the wheel is a waste of money and time. So they went to where the resources-intellectual and mechanical-already existed: the private firms themselves. The use of pre-existing facilities eliminates the need for NIST to maintain a corps of researchers and cutting-edge equipment on-site, thus enabling the agency to save millions of dollars and to concentrate its resources and efforts on identifying the most promising candidates, building and supporting collaboration, and administering the program efficiently.

The concern over efficient administration of the awards has raised fears that rivalry between partners in joint ventures would threaten projects from the inside. Program proponents argue, however, that during the precompetitive stage, a joint venture between multiple organizations that lock the 
ability to gain a particular advantage over each other is viable. ${ }^{22}$ After the $R \& D$ phase is completed, each participant may proceed in its chosen direction with rights to the generic technology, thereby allowing each partner to apply the technology to develop specific products or manufacturing methods for those products. ${ }^{23} \mathrm{~A}$ joint venture currently underway is the Automotive Composites Consortium involving Ford, General Motors, and Chrysler. The "Big Three" automakers are cooperatively investigating the use of structurally reinforced composites in automobiles and the technical hurdles that currently limit the exploitation of this application. ${ }^{24}$

As with its parent organization, the Department of Commerce, some of ATP's functions have provoked further inquiry. Opponents have argued that ATP is needlessly duplicating efforts that exist in other federal organizations. Others question whether the program can ever fulfill its lofty goals. ${ }^{25}$ Finally, the largest issue surrounding the nature of NIST programs like ATP is the level of influence afforded to the federal government over the private sector and the fate of U.S. industry.

\section{Duplication of Efforts}

One issue surrounding the cost-shared awards to industry is the striking similarity ATP bears to programs undertaken by other federal agencies such as the Department of Defense (DOD). On July 25, 1989, Deputy Commerce Secretary Thomas J. Murrin testified before Congress that, "ATP is only one approach for the United States to commercialize new technologies.,26 For example, the Advanced Research Projects Agency (ARPA) program within DOD supports SEMATECH, a consortium of eleven major semiconductor manufacturers, by providing 50 percent of the funds required for the consortium's R\&D. SEMATECH was designed to regain U.S. leadership in semiconductor manufacturing through the development of advanced equipment and the reduction of costs through improved efficiency and quality. ${ }^{27}$ ATP's mission mirrors that of the ARPA, and as of July 25, 1995-six years after the initial report had been issued by the U.S. General Accounting Office-eleven other programs closely resembling ATP and ARPA had been located.

There is no question that ATP appears to duplicate ARPA's programmatic function. ATP was created specifically for the purpose of providing a commercial counterpart to ARPA. Indeed, Congress has been generously funding NIST for years, hoping that the agency would invigorate the struggling manufacturing sector like ARPA did for the semiconductor industry 30 years ago. ${ }^{28}$ Millions of dollars of technology application money and NIST's current director were transferred directly from ARPA to NIST to pursue "dual-use" applications. ${ }^{29}$

Finally, the largest issue surrounding
the nature of NIST programs like ATP is
the level of influence afforded to the
federal government over the private
sector and the fate of U.S. industry.

However, the key difference between the two programs is that ARPA was aimed at a very specific kind of technology, whereas ATP, which relies upon industry to nominate technologies deserving of advancement, supports a much broader selection. John Tesk, a physical scientist with NIST"s Polymers Division, argues that although ATP is one of many government research and development programs, the element of discretion afforded by a broader base of projects from which to choose distinguishes the program from the rest. Unlike similar programs where the primary focus is on basic research or technology development to meet specific mission requirements, ATP's goal is more fluid: "to increase fecleral investment in precompetitive research on generic technologies through cost-sharing partnerships with industry in areas where the federal government is not a major encl-user. ${ }^{1,30}$

The qualifier requiring that efforts and resources be aimed at non-governmental users attached to ATP's goal of promoting research on precompetitive technology highlights the second key element that separates ATP from other government-industry programs: ARPA's major end user was the military. ATP's major end-user is industry. As seen in Figures 1 and 2, ARPA allows government to serve the needs of various departments, whereas ATP permits government to serve the needs of industry and the economy. ATP applicants must prove their current and future worth to the nation, not the government.

When combined with its broad legislative mandate-to promote the rapid commercialization of new scientific discoveries and refine manufacturing practices-NIST's fluid mission gives ATP an element of flexibility and tremendous scope that most other federal programs lack. An ATP document aptly summarizes the agency's strength:

NIST is the only government research organization whose technical capability is not constrained by an operational federal mission. NIST is not defined by responsibility for a particular technology. It is defined instead by the functional requirements of its mission 


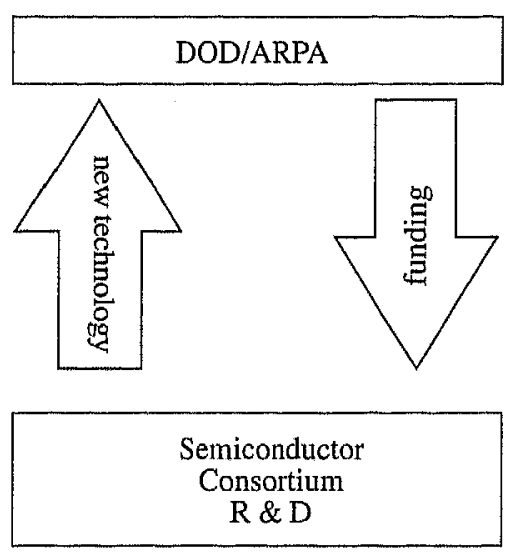

Figure 1. Old Model: closed system

to help the scientific and industrial base as a whole progress technically....Unlike other federal technology programs, ATP makes investments explicitly for this reason rather than for some other national goal. ${ }^{31}$

ATP's approach to commercialization of new technologies is unique among government $R \& D$ support programs. ATP may bear striking similarity to programs such as SEMATE$\mathrm{CH}$, but the likenesses are outweighed by the fundamental difference between ATP's flexible mission and the rigid mission of other fecleral R\&D programs. Flexibility and discretion in choosing which technologies to promote is the fundamental difference between ATP and parallel R\&D programs; however, the amount of bureaucratic discretion has brought NIST unwanted, negative attention.

\section{Intrusion}

One of the larger issues surrounding ATP is the depths to which government is permitted to delve into industrial activities. A former NIST director has remarked that Americans are very confortable with the nation's science policy. "The nation is, however, very uncomfortable with the idea of industrial policy." ${ }^{32}$ Through its funding program, NIST is deciding which technologies the federal government should back by selecting and speeding up critical ones that seem just a grant away from the market. ${ }^{33}$ The dominant philosophical position among citizens and our elected representatives would render this role too intrusive.

Proponents of this view claim that the government, by funding selective corporate efforts, is stepping in where it does not belong, disrupting the natural effects of the market mechanism and needlessly increasing the burden on the taxpayer. Claud Barfield of the American Enterprise

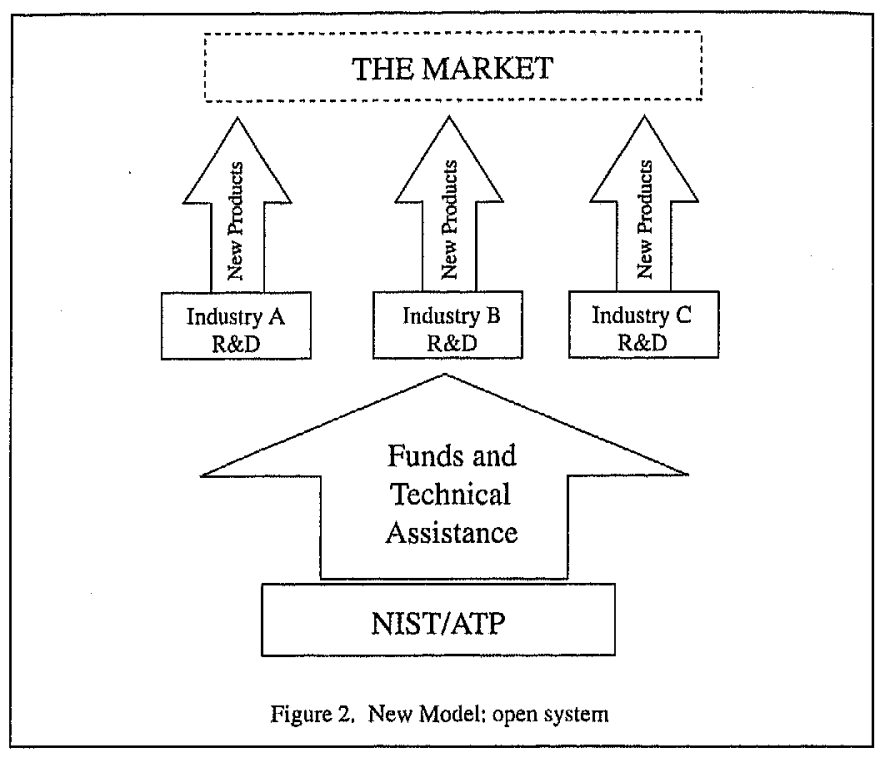

Institute has accused Congress of putting "pressure on ATP to fund product development-something that companies and stockholders rather than taxpayers should subsidize.".34 Likewise, the Bush administration believed that private industry, not the federal government, should take the R\&D lead. Philosophically opposed to the government becoming a venture capitalist for fledgling companies, President Bush's response to Congressional support for NIST programs such as ATP was tepid at best.

In actuality, the prevention of federal intrusion is inherent in ATP's design. While the federal government provides the catalyst for ATP technology projects, industry itself conceives, partially funds, and executes the projects. NIST does not substitute decisions by government bureaucrats for decisions better made by private industry; neither does the agency pick "winners and losers" any more than other federal research agencies such as the National Science Foundation and the National Labs do. ${ }^{35}$ Specific R $\& D$ projects are selected from proposals developed and submitted by industry, thereby allowing industry to set and change the program's agenda. In other words, NIST does not dictate to inclustry what type of research it must pursue. Instead, NIST lets industry propose and defend eminently marketable, pre-competitive technologies that have the potential for wide-spread application and significant market success. Through NIST, the federal government is not simply regulating corporate activity, but proactively responding to business needs, thereby supporting high-tech manufacturers so that they may survive and flourish into the new millennium.

The concerns of conservatives like Barfield, President Bush, and others about government involvement in indus- 
try may have been appropriate during the Cold War. Now, however, this conception of the federal role is invalidated by the changing nature of global competition in recent years. In the complacent 1950s, the United States was the unchallenged global leader in most industries, so efficiency in the transference of new technologies to the market was not a priority. For instance, in the early 1960s, almost 90 percent of the color televisions produced in the world came from the United States. ${ }^{36}$ Now more than half are made in Japan. Similarly, although the VCR is an American invention, the Japanese now manufacture greater than 90 percent of the world's supply. ${ }^{37}$ These days of global competition are vastly different-the competition is fierce and extremely capable.

\section{A New Role}

In a speech at NIST's 90th Anniversary Symposium, former Director Lewis Branscomb acldressed the debate over the appropriate role of government:

Americans are now beginning to recognize the changed status of the American economy, and the need for a more supportive role by government for industrial competitiveness. The starting point for that recognition is awareness that the spin-off model for commercial benefit from mission-driven federal technology is not a sufficient view of how the government should help. ${ }^{38}$

In effect, Branscomb is suggesting that the role played by the federal government in earlier programs such as ARPA would fail to fulfill current industry needs in the face of strong foreign competition. These old models are inefficient in a world where economic victory is now determined by who is first to the market, not first in development.

Since the debut of ATP, NIST leaders have come forward to urge their government peers, industrial partners, and citizens to shed their disillusionment at opportunities for technological advancement and come to terms with reality. In 1991, John Lyons, former Director of NIST, noted that the Omnibus Act of 1988 increased NIST's focus on working with industry in order to improve the competitive posture of U.S. industry in the global marketplace. "Market places are now global rather than national, and U.S. industry is struggling to keep up with some of our off-shore trading partners. ${ }^{139}$ Two years later, the late Commerce Secretary Ron Brown said that: "a raging debate about the proper relationship between industry and the government has ended and government is ready to work hand-in-hand with industry to strengthen the U.S. economy." ${ }^{, 60}$

The question that remains, therefore, is not whether the government should be collaborating with industry but what form that collaboration will take. The ATP can certainly be seen as a model of effective government program design in the future. The program's effectiveness lies in the facilitating rather than the directing of government-industry collaboration. In light of the global competition, the ATP's legislative mandate gives the agency new facilitating and brokering functions: facilitating the agenda of industry and brokering $R \& D$ deals between companies with similar needs and interests. ATP's financial support allows companies to overcome the risk that has always been a roadblock to progress. Also, ATP facilitates collaboration between competing U.S. firms that otherwise would not join forces. In effect, the program removes government from its role as heavy-handed director and places it in an almost pure facilitator role.

The question that remains... is not
whether the government should be
collaborating with industry but what
form that collaboration will take.

This new model of government-industry collaboration has significant far-reaching benefits. First, ATP undoubtedly has a high potential to affect U.S. economic growth. Furthermore, by making direct grants to corporations and consortia instead of conducting the research in-house, NIST has reduced the need for bureaucracy and helped the country move forward. This is inherently a more effective form of government service and one that will necessarily be replicated in this era of reduced funds and increased need.

\section{Continuing a Trend}

NIST continues to shape its programs in response to the changing needs of the country. In 1994, new strategies were outlined for the future of ATP in which it will build cooperative alliances among businesses, universities, and government and propose joint ventures to corporations based on mutual interests. The program will also act as a mentor by assisting companies, particularly small ones, in planning for future commercialization, developing linkages with investors, and implementing business plans.

NIST had its origins in an era of scientific progress, when uniform measurements and commercial standards were 
vital to the successful application of the previous century's innovations. NIST is still a critical agency for facilitating the development and application of new technology. As Dr. Prabhakar said, "Since our beginnings in 1901 we've always been an organization whose job it was to serve industry in extremely practical ways." ${ }^{\text {,t }}$ However, the combination of today's advanced technology, the global economy and the trend toward reduced government places NIST in a role that moves beyond measurements and standards to a new model of government-industry collaboration.

In ATP, NIST has created a benchmark for federal programs-one that reduces the need for a large bureaucracy, makes government more responsive and helps the country move forward by design. Now, NIST's challenge is to further define and refine the new relationship with industry so that, like its early 20th century incarnation, NIST can continue to serve the challenging scientific and technologi$\mathrm{cal}$ needs of the nation. $\star$

\section{Notes}

II wish to thank my editors, Rachel Mosher-Williams, for her constant support and reassurance, and Monika Suarez for her fine-tuning abilities. Also, my appreciation goes to John Tesk of NIST who took the trouble to search his records for an obscure speech given at a symposium many years ago and to Professor Davicl Grier of the University Honors Program at The George Washington University for sharing his enthusiasm on the topic with me. Finally, thanks to Pat Keehley and Steve Medlin for their interest in and support of my academic and career endeavors.

'Dennis F Cioffi, "Clinton Philosophy Transforms NIST into "Partner for Industry," Pbysics Today, November, 1994, 75.

${ }^{2}$ The National Bureau of Stanclards is known today and referred to in this paper as the National Institute for Standards and Technology, NIST.

${ }^{3}$ Senate Committee on Governmental Affairs, Government's Role in Economic Competitiveness: Hearing before the Committee on Governmental Affairs, 100th Cong., 1st sess., 8 June 1987, 1.

${ }^{4} I b i d ., 1$.

${ }^{5}$ Public Law, 100-418.

"Jerome Cramer, "NIST: Measuring Up to a New Task," Science, 26 March 1993, 1818.

'Cioffi, 75.

"Senate Committee on Governmental Affairs, 44.

'U.S. Statutes at Large 102 (1988): 1107. Omnibus Trade and Competitiveness Act.

${ }^{10} \mathrm{Ibid}$. Among its other functions and activities, NIST would serve as an information resource for trade associations, state technology programs, labor organizations, professional societies, and educational institutions, and continue carrying out its original mission of ensuring preciseness in measurements, calibrations, and standards that would help U.S. industry compete in world markets.

"Ibid.

${ }^{12}$ Wil Lepkowski, "NIST Launches Technology Centers," Cbemical \& Engineering News, 9 January 1989, 26.

${ }^{13}$ U.S. Statutes at Large 102 (1988): 1107. Omnibus Trade and
Competitiveness Act.

${ }^{14}$ Ibid.

${ }^{15}$ Senate Committee on Governmental Affairs, 1.

"David S. Cloud, "Panel Boosts NIST High-Tech Role," Congressional Quarlerly Weekly Report, 5 August 1989, 20282029.

"17"NIST: Firing Up U.S. Industry," Edited by Richard Stone, Science, 1 January 1993, 19.

${ }^{18}$ Dr. Arati Prabhakar as quoted by Cioffi, 75 .

${ }^{19}$ Since its founding, ATP has been open to any type of proposal involving high-tech, high-risk projects. But in April 1994, the Department of Commerce identified five focused program areas: tools for DNA diagnostics, information infrastructure for health care, manufacturing advanced composite structures, component-based software, and computer-integrated manufacturing for electronics.

${ }^{20} \mathrm{Cioffi}, 77$.

${ }^{21}$ Lepkowski, 26.

${ }^{22}$ Precompetitive means an emerging technology with widespread commercial application potential.

${ }^{23}$ John Tesk, "The National Institute for Science and Technology and its Advanced Technology Program: A New Model for Government/Industry Innovation," Journal of NIH Research, L.P., (Part 3): 13.

${ }^{24}$ Ibid, 14 .

${ }^{25}$ The question of whether ATP is producing results and meeting expectations is difficult to answer. In his statement to the Senate Committee on Governmental Affairs, L. Nye Stevens, Director of Federal Management and Workforce Issues, said, "Our May 1995 report examined NIST's efforts to evaluate ATP. We concluded that it was too early to determine ATP's long-term economic impact. However, our analysis indicated that short-term results that NIST had identified in a January 1994 report were overstated or lacked adequate support. In addition, NIST's proposed use of technical milestones and the number of collaborations and strategic alliances to evaluate A'TP may create false expectations of its economic success."

${ }^{26}$ Cloud, 2028.

${ }^{27}$ U.S. General Accounting Office, Government Reorganization: 
Observations on the Department of Commerce. GAO/TGGD/RCED/AIMD-95-248, Washington, DC., July 1995, 9.

"NIST: Firing Up Industry," 19.

${ }^{29}$ The term dual-use means civilian and military applications,

${ }^{30}$ Tesk, 14.

${ }^{31}$ U.S. Department of Commerce, Technology Administration, National Institute of Standards and Technology. NBS/NIST $A$ Historical Perspective: A Symposium in Celebration of NIST's Ninetieth Anniversary, Edited by Karma Beal, Gaithersberg, MD, 1992, 29.

${ }^{32}$ Ibid., 28. Industrial policy refers to the statement of U.S. goals for industrial and manufacturing enterprises in which the federal government has an explicit role.

${ }^{33}$ Bob Davis, "The Cutting Edge: An Old, Quiet Agency Has Suddenly Become a High-Tech Leader," The Wall Street
Journal, 5 April 1994, A1.

${ }^{3}$ Cramer, 1819.

${ }^{35}$ Senate Committee on Governmental Affairs, 2.

36Ibid., 44.

${ }^{37}$ Ibid., 44 .

${ }^{3}$ U.S. Department of Commerce, Technology Administration, National Institute of Standards and Technology, 28.

${ }^{39} \mathrm{Ibid}, \mathrm{,} 5$.

${ }^{40}$ Frederick Golden and Jeffrey Mervis, "Choice to Head NIST Defines Shift in U.S. Technology Policy," Nature, April 29, 1993, 777.

${ }^{41}$ Dr. Arati Prabhakar as quoted by John Teresko, "NIST: More Than Weights and Measures," Industry Week, 19 December 1994, 80 .

\section{Bibliography}

Abelson, Philip H. "National Institute for Science and Technology." Science, 20 May 1994, 1063.

Barr, Stephen. "6,000 Could Lose Jobs at Commerce." The Wasbington Post, 14 October 1995.

Barr, Stephen. "At Hill Agency, the End Is Near." The Washington Post, 28 September 1995.

Barr, Stephen. "Rift Over the Pink Slip." The Washington Post, 8 September 1995.

Cioffi, Denis F. "Clinton Philosophy Transforms NIST into "Partner for Industry." Pbysics Today, November 1994, 75-77.

Cloud, David S. "Panel Boosts NIST High-Tech Role." Congressional Quarterly Weekly Report, 5 August 1989, 20282029.

Couch, Robin L. "How Tough Is It to Win the Baldrige?" Financial Executive, May/June 1991, 4-5.

Cramer, Jerome. "NIST: Measuring Up to a New Task." Science, 26 March 1993, 1818-1819.

Davis, Bob. "The Cutting Edge: An Old, Quiet Agency Has Suddenly Become a High-Tech Leader; National Institute of Standards Will Pick Key Inclustries, Step Up Research Grants but Critics Allege Favoritism." The Wall Street Journal, 5 April 1994.

Federal Regulatory Directory. Edited by Jon Preimesberger. Washington, D.C.: Congressional Quarterly Inc., 1994.

Golden, Frederic and Jeffrey Mervis. "Choice to Head NIST Defines Shift in U.S. Technology Policy." Nature, 29 April 1993, 777.

Goodwin, Irwin. "Congress Enacts 1995 R\&D Budgets, With NIST and NSF the Big Winners." Pbysics Today, October 1994, 59-61.
Gray, Martha and Kathy Liburdy, "Testers Open Dialogue at Inaugural NIST Workshop." IEEE Software, September 1994, $120-121$.

Holusha, John. "Profile/Arati Prabhakar; She's Not Just Setting Standards," The New York Times, 1 August 1993.

Lepkowski, Wil. "New NIST Director Breaks Traditions," Chemical \& Engineering Neus, 5 April 1993, 7-8.

Lepkowski, Wil. "NIST Launches Technology Centers." Chemical E Engineering News, 9 January 1989, 26.

Lyons, John W. "Competitiveness, Technology, and the Role of Government." U.S. Cbemical Industry in International Markets, 86, no. 274: 1-7.

Morgan, Dan. "Budget-Cutter Hits Reality." The Washington Post, 8 September 1995.

"NIST: Firing Up U.S. Industry." Edited by Richard Stone. Science, January 1, 1993, 19.

Sawyer, Kathy. "Gore's Scientific Approach to GOP Cuts." The Wasbington Post, 28 February 1996.

"SEMI/SEMATECH Home Page." The World Wide Web, http://www.sematech.org/semi- semitech/home.htm.

Silber and Associates. "Survey of Advanced Technology Program 1990-1992 Awardees: Company Opinion About the ATP and Its Early Effects." Silber and Associates, Clarksville, MD, 1996. Photocopy.

Teresko, John. "NIST: More Than Weights and Measures." Industry Week, 19 December 1994, 75, 78, 80.

Tesk, John. "The National Institute for Science and Technology and its Advanced Technology Program: A New Model for Government/Industry Innovation." Journal of NIH Research, L.P., (Part 3): 13-14.

U.S. Department of Commerce. "Advanced Technology Program Announces New Focus Areas, Secks Proposals for 
1995 General Competition ." United States Department of Commerce News. Washington, D.C., 1994.

U.S. Department of Commerce. "NIST Announces 21 New Advanced Technology Program Awards." United States Department of Commerce News. Washington, D.C., 1995.

U.S. Department of Commerce. "NIST Announces 24 New Advanced Technology Program Awards." United States Department of Commerce News. Washington, D.C., 1995.

U.S. Department of Commerce. "NIST Announces 44 New Advanced Technology Program Awards." United States Department of Commerce News. Washington, D.C., 1995.

U.S. Department of Commerce. "U.S. Industries from Medicine and Electronics to Agriculture and Materials to Gain from Commerce Awards." United States Department of Commerce News. Washington, D.C., 1994.

U.S. Department of Commerce, Technology Administration, National Institute of Standards and Technology. Advanced Tecbnology Program. Gaithersburg, MD, 1994.

U.S. Department of Commerce, Technology Administration, National Institute of Standards and Technology. Advanced Tecbnology Program. Gaithersburg, MD, 1995.
U.S. Department of Commerce, Technology Administration, National Institute of Standards and Technology. Advanced Tecbnology Program Proposal Preparation Kit. Gaithersburg, MD, 1994.

U.S. Department of Commerce, Technology Administration, National Institute of Standards and Technology. NBS/NIST A Historical Perspective: A Symposium in Celebration of NIST's Ninetieth Anniversary. Edited by Karma Beal. Gaithersburg, MD, 1991.

U.S. General Accounting Office, Government Reorganization: Observations on the Department of Commerce. GAO/TGGD/RCED/AIMD-95-248, Washington, D.C., July 1995.

U.S. General Accounting Office. High Performance Computing and Communications: New Program Direction Would Benefit From a More Focused Effort. GAO/AIMD-95-6 Washington, D.C., November 1994.

U.S. General Accounting Office. NIST's Unobligated Funds. GAO/RCED-95-166R Washington, D.C., May 1995.

U.S. Statutes at Large 102 (1988): 1107. Omnibus Trade and Competitiveness Act. 